Original Article

\title{
Effectiveness of hair lead concentration as biological indicator of environmental and professional exposures.
}

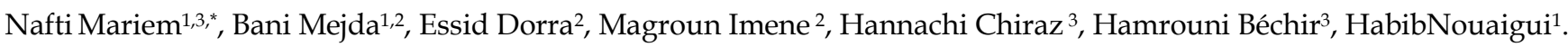

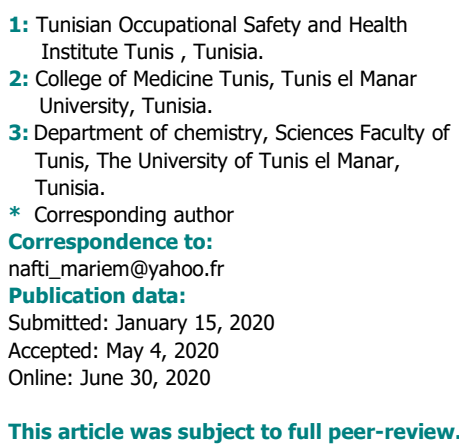

This is an open access article distributed under the terms of the Creative Commons Attribution NonCommercial License 4.0 (CCBY-NC) allowing to share and adapt.

Share: copy and redistribute the material in any medium or format.

Adapt: remix, transform, and build upon the licensed material.

the work provided must be properly cited and cannot be used for commercial purpose.

\section{Abstract:}

Introduction:

Biological monitoring is highly recommended to assess occupational and environmental exposures to toxic chemicals. In this context, blood and urine are conventional matrices for lead poisoning biotoxicological assessment. Blood and urine analysis are more contributive for recent lead exposure. Chronic lead exposure may have different characteristics.

long-term exposure could be responsible of insidious poisoning which cannot always be assessed by these usual matrices. The aim of this study is to demonstrate that human hair can be used as an alternative matrix to detect chronic toxic exposure among occupationally and non-occupationally leadexposed subjects.

Material and Method:

This case-control study analyzed blood, urine and hair sampled from 40 exposed workers versus a control group of 30 . Particulate matters of lead are collected from different workplace ambient air. Analysis is realized using the graphite furnace atomic absorption spectrometry. Correlations are studied between the different matrices in both groups and between seniority and lead concentrations in biological samples.

\section{Results}

This study concerned 70 male subjects: forty battery manufacturing factory workers and thirty controls (non-exposed to lead in their workplaces). The results showed a significant correlation between lead levels in the three matrices and the intensity of exposure among both groups (Pb hair-blood $\mathrm{P}=0.017 ; \mathrm{Pb}$ hair-urine $<0.000$ ). Hair lead concentrations study among cases in function of occupational seniority confirmed the stability of this matrix $(\mathrm{Pb}>3000 \mu \mathrm{g} / \mathrm{g}$ of hair at 20 years). The study of hair lead concentration according to workplace showed a significantly higher exposure for the station of assemblers.

\section{Conclusion}

Hair is an efficient biological sample to assess lead poisoning especially for chronic exposure. Hair is easy to collect, to handle and gives reproducible results that may be useful in monitoring of exposed workers.

Key words

Lead poisoning, monitoring, exposure, hair samples.

Citation: Nafti M, Bani M, Essid D, Magroun I, Hannachi C, Hamrouni B, et al. Effectiveness of hair lead concentration as biological indicator of environmental and professional exposure. Jr. med. res. 2020; 3(2):11-14. Nafti et al @ All rights are reserved. https://doi.org/10.32512/jmr.3.2.2020/11.14 


\section{Introduction}

Lead $(\mathrm{Pb})$ has many useful properties in various industrial sectors such as battery and ammunition manufacturing. This ubiquitous heavy metal is toxic and considered as a cumulative poison that causes several health problems. According to an investigation carried out in Tunisia by the Tunisian Occupational Risk Cartography, 6714 workers are exposed to lead. This represented around $1 \%$ of the total number of workers in 2016 [1-3]. Lead can cause many health problems such as digestive disorders, tubular nephropathies, and hemolytic anemia. For Pb-Blood levels $>600 \mu \mathrm{g} / \mathrm{L}$, peripheral neuropathy, encephalopathy, psychological syndromes can be observed. For the assessment of occupational safety, an effective biomarker that could reflect chronic lead exposure is required. Human hair is one of the major vehicles of the substances excretion. Several studies revealed that hair levels are significantly higher than those of blood or urine regarding exposure to heavy metals. Hair is widely used in forensic medicine. Recently, it became more exploited in clinical and biological monitoring tests $[4,5]$. The advantages include sample stability, easy storage, and significant levels in long-term chemicals exposure.

This study tried first to verify the correlation between lead levels in hair, blood, and urine.

The second aim was to assess lead exposure levels in different workplaces in order to implement biomonitoring preferences according to each matrix lead concentration.

\section{Materials and Methods}

The study was conducted in a battery manufacturing factory. Samples were taken from male volunteers belonging to the same age group. Written informed consent was obtained from all participants before sampling.

The study was approved by our ethics committee according to the Helsinki declaration principles. Forty exposed workers and thirty controls were included. Sensitive methods are employed for the occupational and environmental lead exposure assessment.

Electro-thermal atomization atomic absorption spectrometry (ETAAS) was used to detect lead in air, blood and urine. Methods analytical performances were checked according to ISO17025 exigencies to ensure the reliability of the results. Linearity $\left(R^{2}>0.998\right.$ for blood and urine and $>0.999$ for hair samples and air), fidelity and recovery were studied.

The limits of detection are close to $1 \mu \mathrm{g} / \mathrm{L}$. The washing protocol of hair samples with acetonitrile and water ensured the elimination of more than $98.6 \%$ of external contamination. Storage of samples was codified to avoid inter-contamination.

Environmental measurements

The atmospheric measurements are performed by taking ambient air samples from different workstations. Cellulose ester filters are used (porosity $0.8 \mu \mathrm{m}$ and $37 \mathrm{~mm}$ diameter). After acid mineralization, Lead is quantified using graphite furnace atomic absorption spectrometry.

Reagents and chemicals

Chemicals and reagents used in this study are of analytical grades.

Standard solutions of lead are prepared daily by dilution of 1000 mg.L-1stock solutions provided by Fluka (Madrid, Spain).

Lead stock standard solutions 1g.L-1 is supplied by Merck (Darmstad, Germany). Nitric acid $69 \%$ is obtained from Merck (Darmstad, Germany). Hydrogen peroxide $33 \%$ was supplied by Fluka (Madrid, Spain).
Hydrochloric acid $37 \%$ was obtained from (Sigma-Aldrich). Acetone $99.7 \%$ was provided Carlo Erba (Milan, Italy) and was used to decontaminate the samples. Deionized water of $18{\mathrm{M} \Omega \mathrm{cm}^{-1}}^{-1}$ resistivity is obtained by introducing bi-distilled water in Milli-Q water system (Millipore Corporation, MA, USA).

All plastic and glassware were soaked overnight in nitric acid to avoid contamination.

Apparatus

Jena Zeenit 700P Analytic model atomic absorption spectrometer with deuterium background correction, including a transversely heated graphite atomizer was used. Lead hollow-cathode lamp was used as a radiation source. Measurement of lead concentrations was performed using an MP60 sampler and pyrolytical graphite platform tubes (Analytik Jena, part number 407-A85.025).

Parameters for electro-thermal atomic absorption spectrometer (ETAAS) are optimized and validated in all matrices (air, blood, urine and hair).

These parameters are presented in Table 1.

Samples collection

Blood samples were collected in heparinized tubes. Urine samples were collected in clean bottles. These samples were transported and conserved in the laboratory at $4^{\circ} \mathrm{C}$. Hair samples, with length between 1 and $4 \mathrm{~cm}$, and $0.5 \mathrm{~cm}$ in diameter were cut close to the origin in the occipital area. The samples were identified and stored at room temperature in plastic bags.

Statistics

Data analysis was performed using the sixth version of Epi-InfoTM software IBM SPSS statistics version 21 (Chicago, IL, USA). The validity of the models for comparison of means was studied using the ANOVA test. Significance was retained for $P$ value $<0.05$.

\begin{tabular}{|lllll|}
\hline \multicolumn{4}{|l|}{ Table 1: Operating parameters for Lead analysis using ET-AAS* } \\
\hline Parameters \\
\hline Lamp current $(\mathrm{mA})$ & 4.0 & & \\
\hline Air flow rate $\left(\mathrm{mL} \cdot \mathrm{min}^{-1}\right)$ & 5 (stopeed during atomizing) & & \\
\hline Sample volume $(\mu \mathrm{L})$ & 20 & & & \\
\hline Furnace program & Blood & Urine & Hair & Air \\
\hline Drying $\left({ }^{\circ} \mathrm{C}-10\right.$ seconds) & 140 & 140 & 120 & 120 \\
\hline Ashing $\left({ }^{\circ} \mathrm{C}-10\right.$ seconds) & 700 & 500 & 500 & 400 \\
\hline Atomizing $\left({ }^{\circ} \mathrm{C}-10\right.$ seconds) & 1500 & 1500 & 1500 & 1500 \\
\hline Cleaning $\left({ }^{\circ} \mathrm{C}-10\right.$ seconds) & 2000 & 2000 & 2000 & 2000 \\
\hline
\end{tabular}

\section{Results}

This study concerned 70 male subjects: forty battery manufacturing factory workers and thirty controls (non-exposed to lead in their workplaces). Cases are aged between 22 years and 63 years with a median of 41 years.

Controls are aged between 27 years and 54 years with a median of 36 years (table 2 ).

Workstations occupied by exposed workers are distributed into seven stations noted " $\mathrm{P}$ ":

$\mathrm{P} 1$ : lead pulp preparation operator,

$\mathrm{P} 2$ : grid operator,

P3 : lead pulp pasting operator,

P4 : assembler,

P5 : machine operator

Citation: Nafti M, Bani M, Essid D, Magroun I, Hannachi C, Hamrouni B, et al. Effectiveness of hair lead concentration as biological indicator of environmental and professional exposure. Jr. med. res. 2020; 3(2):11-14. Nafti et al (c) All rights are reserved. 
Effectiveness of hair lead concentration as biological indicator of environmental and professional exposure.

\begin{tabular}{|ccccc|}
\hline \multicolumn{5}{|c|}{ Table 2: Age characteristics of case and control groups } \\
\hline Group & Age Interval & Average & SD* & Median \\
Cases & $22-63$ & 37.6 & \pm 6.8 & 41 \\
Controls & $27-54$ & 33,5 & \pm 4.5 & 36 \\
\hline
\end{tabular}

P6 : electrician,

P7 : welder.

After analyzing biological samples of the studied groups in the different sites, the results showed important lead exposure among workers. Lead levels among workers and controls are shown in table 3. The difference between these groups was more highlighted through the hair matrix, rather than blood and urine samples.

The set of biological samples, which was taken from workers active in the 7 workstations, was used to study the correlation between lead levels and environmental contaminations. The obtained lead values were present in table 4.

\begin{tabular}{|c|c|c|c|c|c|c|}
\hline \multicolumn{3}{|c|}{ Pb-Blood $(\mu \mathrm{g} / \mathrm{L})$} & \multicolumn{2}{|c|}{ Pb-Urine $(\mu \mathrm{g} / \mathrm{g}$ creatinine) } & \multicolumn{2}{|c|}{ Pb-Hair $(\mu \mathrm{g} / \mathrm{g})$} \\
\hline & Case & Control & Case & Control & Case & Control \\
\hline Pb level & $447-1389$ & $64-140$ & $120-430$ & $13-38$ & $177-8367$ & $0.28-6.2$ \\
\hline Average $\pm \mathrm{SD}^{*}$ & $804 \pm 191.8$ & $93.8 \pm 25.5$ & $330 \pm 16.4$ & $24 \pm 5.9$ & $2091 \pm 194$ & $13 \pm 1.5$ \\
\hline Median & 794 & 88.5 & 200 & 24 & 1584 & 1.5 \\
\hline
\end{tabular}

\begin{tabular}{|c|c|c|c|c|c|c|c|c|}
\hline Workstation & P1 & P2 & P3 & P4 & P5 & P6 & P7 & Average \\
\hline $\mathrm{Pb}(\mathrm{mg} / \mathrm{m} 3)$ & 0.13 & 0.25 & 0.17 & 1.72 & 0.14 & 0.03 & 0.51 & 0.42 \\
\hline Pb-Blood( $\mu$ g/L) & 840 & 786 & 818 & 872 & 850 & 745 & 809 & 817.14 \\
\hline $\begin{array}{c}\mathrm{Pb} \text {-Urine }(\mu \mathrm{g} / \mathrm{g} \\
\text { creatinine) }\end{array}$ & 200 & 200 & 224 & 235 & 230 & 200 & 280 & 224.14 \\
\hline Pb-Hair $(\mu g / g)$ & 2473 & 2126 & 1920 & 2040 & 871 & 1757 & 1380 & 1795.29 \\
\hline
\end{tabular}

\begin{tabular}{|lcc|}
\hline \multicolumn{2}{|c|}{ Table 5: Correlation between biologic matrices among cases and controls $\mathrm{R}(\mathrm{p}<0.05)}$. \\
\hline & Cases & Controls \\
\hline (Pb-Hair) $-(\mathrm{Pb}-\mathrm{Blood})$ & 0.017 & 0.67 \\
& -0.21 & 0.60 \\
(Pb-Hair) $-(\mathrm{Pb}-$ Urine $)$ & 0.8 & 0.48 \\
(Pb-Blood) -(Pb-Urine) & & \\
\hline
\end{tabular}

\begin{tabular}{|c|c|c|c|}
\hline Occupational seniority & Pb-Blood $(\mu \mathrm{g} / \mathrm{L})$ & Pb-Urine ( $\mu \mathrm{g} / \mathrm{g}$ creatinine) & Pb-Hair $(\mu g / g)$ \\
\hline$<2$ years & 745.25 & 140 & 1123.5 \\
\hline $2-10$ years & 749.47 & 213.84 & 2200.33 \\
\hline $11-20$ years & 826.4 & 233 & 2490.7 \\
\hline$>20$ years & 799.5 & 235 & 3335.75 \\
\hline
\end{tabular}

The highest intensity of exposure corresponded to the station $\mathrm{P} 4$ where the highest level of $\mathrm{Pb}$ in blood was noted. However, the highest amount of lead in hair samples was found in the station P1. The correlations between the different biological associations (hair-blood, hair-urine, and blood-urine) among cases and controls were present in the table 5 .

Lead levels in worker's samples were present in terms of seniority, which was divided in 4 intervals (Table 6).

\section{Discussion}

The maximum-tolerated doses for lead in biological matrices are $400 \mu \mathrm{g} / \mathrm{L}$ in blood and $25 \mu \mathrm{g} / \mathrm{g}$ creatinine in urine $[6,7]$. Lead exposure in the studied manufacture employees can be assessed by comparing $\mathrm{Pb}$ values in worker and control groups. The average of lead concentration in air samples is $0.42 \mathrm{mg} / \mathrm{m} 3$ while the maximum allowed level is $0.2 \mathrm{mg} / \mathrm{m} 3$ [10]. This could explain the high lead concentrations in our studied workers' samples. Blood lead level may reflect both recent and chronic exposures. In long-term exposures, high lead rates could be related to the mobilization of stored metal from bone and soft tissues [8-10].The environmental exposure to lead in Tunisia is relatively lower compared to other countries. The average $\mathrm{Pb}$-Hair of control group was only $2.9 \mu \mathrm{g} / \mathrm{g}$ in our series.

This is still comparable to the rates of other industrialized countries such as Poland and Italy [11]. Lead levels in biologic matrices are particularly high in exposed workers. In our study, the workstation highest $\mathrm{Pb}$-Blood and $\mathrm{Pb}$-Urine concentrations did not match those with the highest $\mathrm{Pb}$-Hair levels. This could signify that the exposure-intoxication relationship is multifactorial[12,13].

The hair lead concentration seems to be higher and more stable in case of long-term exposures.

The rates may be influenced by the logistic and human communications between different workstations [14]. The hair lead concentration is significantly correlated to the design of the workplace and to the implementation of personal protection policy.

The correlation between the lead concentration in biological matrices and its concentrations in hair may be evident and was verified by several studies[14-16].

The stability of the hair as matrix and its direct interference with the environmental sources of exposure may be origin of the fluctuations in the results of some other studies [17]. The significant correlation between $\mathrm{Pb}$-hair and $\mathrm{Pb}$-blood suggests the efficiency and effectiveness of using hair for assessing occupational exposure specially in highly polluted areas [18-20].

The results of this study contribute one more time to the recommendation of the reinforcement of personal worker protection and implementation of clear a safety policy. The aim is to reduce the consequences of intoxication especially in worker population with several comorbid factors. 
Effectiveness of hair lead concentration as biological indicator of environmental and professional exposure.

\section{Conclusion}

This study highlighted the effectiveness of using of human hair as a biological marker of occupational chronic lead exposure and its confrontation to the conventional used matrices (Blood and urine) which are more contributive in acute lead poisoning. However, the lack knowledge especially regarding hair maximum concentration limits and the interference of some environmental and personal factors in the exposure mechanism may limit the usefulness of this matrix. Lead hair concentration could help in monitoring environmental and occupational pollution. Moreover, hair provides a memory of past long-term lead exposure.

The hair is easy to collect and provides stable samples. Its study could contribute reproducible information useful in the follow-up of exposed population.

\section{Conflict of interest: None}

\section{References}

[1] Ma H, Suhling JC. A review of mechanical properties of lead-free solders for electronic packaging. ] Mater Sci.2009; 44: 1141-58

2] Carocci A, Catalano A, Lauria G, Sinicropi MS, Genchi G. Lead toxicity, antioxidant defense and environment. Rev Environ Contam Toxicol. 2016;238:45-67.

3] Cartographie des Risques Professionnels en Tunisie Juillet 2018.Ministère des affaires sociales. Available from: http://www.social.gov.tn [accessed date $2020 \mathrm{Feb} 28$ ]

[4] Garnier R. Toxicité du plomb et de ses dérivés. EMC Tox Path.2005;2:67-88.

[5] Sakai T. Biomarkers of lead exposure. Ind Health. 2000;38:127-42.

[6] Trojanowski P, Trojanowski J, Antonowicz J, Bokiniec M. Lead and cadmium content in human hair in Central Pomerania [Northern Poland]. J Elem. 2010;15:363-84

[7] Gil F, Hernández AF, Márquez C, Femia P, Olmedo P, López-Guarnido $O$, et al. Biomonitorization of cadmium, chromium, manganese, nickel and lead in whole blood, urine, axillary hair and saliva in occupationally exposed population. Sci Total Environ. 2011;409:1172-80.

[8] Trzeciakowski JP, Gardiner L Parrish AR. Effects of environmental levels of cadmium, lead and [8] Trzeciakowski JP, Gardiner L, Parrish AR. Effects of environmental levels of cadmium, lead and mer

9] Hu SS, Cai SZ, Kong XZ. Chronic Lead Exposure Results in Auditory Deficits and Disruption of Hair Cells in Postweaning Rats. Oxid Med Cell Longev. 2019;2019:4289169.

[10] Dubiella-Jackowska A, Polkowska $Z$, Namieńnik J. Platinum group elements in the environment: emissions and exposure. Rev Environ Contam Toxicol. 2009;199:111-35.

[11] Zhu KY, Leung KW, Ting AKL, Wong ZCF, Ng WYY, Choi RCY, et al. Microfluidic chip based nano liquid chromatography coupled to tandem mass spectrometry for the determination of abused drugs and metabolites in human hair. Anal Bioanal Chem. 2012;402:2805-15.

[12] Koh D-H, Locke SJ, Chen Y-C, Purdue MP, Friesen MC. Lead exposure in US worksites: A literature review and development of an occupational lead exposure database from the published literature. Am J Ind Med. 2015;58:605-16.

[13] Serrazina DC, Andrade VLD, Cota M, Mateus ML, Aschner M, Dos Santos APM. Biomarkers of exposure and effect in a working population exposed to lead, manganese and arsenic. J Toxicol Environ Health A. 2018;81:983-97.

[14] Strumylaite L, Ryselis S, Kregzdyte R. Content of lead in human hair from people with various exposure levels in Lithuania. Int J Hyg Environ Health. 2004;207:345-51.

[15] Nnorom IC, Igwe JC, Ejimone JC. Multielement analyses of human scalp hair samples from three distant towns in southeastern Nigeria. Afr J Biotechnol. 2005:4:1124-27.

[16] Michalak I, Wołowiec $P$, Chojnacka K. Determination of exposure to lead of subjects from southwestern Poland by human hair analysis. Environ Monit Assess. 2014;186:2259-67.

[17] Nkomo $P$, Richter LM, Kagura J, Mathee $A$, Naicker $N$, Norris SA Environmental lead exposure and [ 629:1437-45

[18] Zhang $Y$, Jiang $Q$ Xie $S$, Wu X, Zhou J, Sun $\mathrm{H}$. Lead Induced Ototoxicity and Neurotoxicity in Adut Guinea Pig. Biomed Res Int. 2019;2019:3626032.

[19] [19] Serdar MA, Akin BS, Razi C, Akin O, Tokgoz S, Kenar L, et al. The Correlation Between Smokin Status of Family Members and Concentrations of Toxic Trace Elements in the Hair of Children. Biol Trace em Res. 2012;148:11-17.

20] Molina-Villalba I, Lacasaña M, Rodríguez-Barranco M, Hernández AF, Gonzalez-Alzaga B, AguilarGarduño $C$, et al. Biomonitoring of arsenic, cadmium, lead, manganese and mercury in urine and hair of children living near mining and industrial areas. Chemosphere. 2015;124:83-91

[21] Nouioui MA, Araoud M, Milliand M-L, Bessueille-Barbier F, Amira D, Ayouni-Derouiche L, et al. Biomonitoring chronic lead exposure among battery manufacturing workers in Tunisia. Environ Sci Pollut Res. 2019;26:7980-93

[22] Mohamed Fel B, Zaky EA, El-Sayed AB, et al. Assessment of Hair Aluminum, Lead, and Mercury in a Sample of Autistic Egyptian Children: Environmental Risk Factors of Heavy Metals in Autism. Behav Neurol. 2015;2015:545674.

Citation: Nafti M, Bani M, Essid D, Magroun I, Hannachi C, Hamrouni B, et al. Effectiveness of hair lead concentration as biological indicator of environmental and professional exposure. Jr. med. res. 2020; 3(2):11-14. Nafti et al (c) All rights are reserved. 